\title{
Islam in the academic sphere in senegal: the case of Cheikh Anta Diop University in Dakar (UCAD)
}

\author{
El Hadji Malick Sy Camara ${ }^{1,2}$. Mamadou Bodian ${ }^{3}$
}

Published online: 13 June 2016

(C) The Author(s) 2016. This article is published with open access at Springerlink.com

\begin{abstract}
This paper discusses the changing socio-cultural landscape at Cheikh Anta Diop University of Dakar (UCAD), Senegal. It shows how the growing influence of the religious phenomenon since the late 1970s has encouraged young students to develop an Islamic activism that tends to replace the revolutionary and secular traditions that had dominated the space since the founding of this Senegalese university in 1957. These transformations, which take the form of a "decomplexification" of religion and of a communitarisation of the academic sphere, are also a reflection of the ongoing transformations in Senegalese society marked by a citizenship in transition. This transition translates itself into a duality between a "national citizenship," with a francophone and secular character, and a "cultural citizenship," inspired by Islam and initially driven by an Arab-Islamic elite as it negotiates its place in the public and administrative spheres that have historically been dominated by francophone elites.
\end{abstract}

Keywords Islam · Dakar · Senegal · University · Citizenship · Public sphere · Decomplexification $\cdot$ Communitarisation

\section{Introduction}

The socio-cultural landscape at Cheikh Anta Diop University of Dakar (UCAD) is undergoing an unprecedented evolution. With the growing influence of religious phenomena since the late 1970s, young students are developing an Islamic activism that tends to replace the

El Hadji Malick Sy Camara

elhadjimalicksy.camara@ucad.edu.sn

1 Department of Sociology, Cheikh Anta Diop University of Dakar (UCAD), Dakar, Senegal

2 International Mixed Research Unit "Environment, Health and Societies", UMI 3189/UCAD/ CNRS, Dakar, Senegal

3 Centre for African Studies, University of Florida, 427 Grinter Hall, PO Box 115560, Gainesville, FL 32611-5560, USA 
revolutionary traditions of the student movement and challenge the secular nature of the academic sphere. This change is all the more intriguing because, since its creation in 1957 , the University of Dakar had been a place where revolutionary ideologies reigned without competition. Communist currents fed the thinking and actions of the first generations of students. They generally sided with left-wing intelligentsia and used the student unions as a way around the politics of the ruling class (Diop 1992; Thioub 1992). The founding statutes and charters of these student organisations therefore emphasised their apolitical and secular nature. For example, Article 6 of Decree No. 68-860 of 24 July 1968 on student associations in higher education states:

"The General Union of Students of the University can only be established as a federation of corporate associations of faculties or legally constituted schools [...] Its sole purpose is to defend the students' material and moral interests with the academic and government authorities. It prohibits all activities contrary to its apolitical vocation as well as taking any position in religious matters."

In practice, the principle of an apolitical and a-religious student movement never really prevailed. Students always projected their political ideas and moral principles onto the public university sphere. If we consider protest, sport, culture and religious activities as the constitutive centres of the student movements, the first was the main focus of action (Ndiaye 2007). Since the student movement was more inclined to be involved with ideological and political struggles, the campus was known for its tradition of rejecting any form of religious expression from 1957 to 1970 (Ndiaye 2007: 118). But today, revolutionary and secular ideologies compete with religion over this sphere, with religion being a vector of an ideal based on the faith in God. One can rightly ask oneself why and how religion has been able to take up such an important place within the academic sphere today. More precisely, how have student groups been able to develop an Islamic activism at the expense of revolutionary and secular ideologies?

This article explores the ascendance of the Islamic phenomenon at Cheikh Anta Diop University of Dakar (UCAD) and focuses on students as a social category that is turning more and more towards Islam. The objective is to show how and why secularism and revolutionary ideologies have progressively lost their ability to structure the academic sphere at a time when Islam and Islamic organisations have emerged as imposing actors.

Our first main argument is that the assertion of Islam at UCAD is the consequence of a "decomplexification" of religion and the "communitarisation" of the academic sphere that has resulted from the decline of revolutionary and secular ideologies. In other words, as the revolutionary and secular ideologies lose ground, religious ideology affirms itself and conquers the academic sphere. Decomplexification of religion should be understood as comprising two related aspects. It refers on the one hand to the emancipation of students who have succeeded in overcoming their sense of insecurity (i.e. their hesitation to assert their identities, or "complexes") as Muslims in a university space dominated by revolutionary and secular ideologies. At the same time it reflects the process by which one or more religious groups construct their identity in the university space. It is a process of affirmation in time and space where, through religious activities, the individual identity or collective identity of a group is enacted

${ }^{1}$ Collection of legal texts regarding the Cheikh Anta Diop University, September 1995. 
through public expression of their religious faith. Decomplexification thus refers to a process in which the mere presence or representation of religion leads to its affirmation in the academic sphere, without complexes. It often results into what might be called the "communitarisation" of space. This communitarisation leads to the emergence of new forms of group solidarity and the invention of a secondary (or doctrinal) space of socialisation which plays an important role in the process of decomplexification of religion. Simultaneously, this communitarisation leads to a fragmentation of Islam into Sufi trends and other doctrinal subgroups, each with its own characteristics. This visibility marks and proves their decompartmentalisation. To a certain extent, this fragmentation of Islam challenges the ideal of citizens living peacefully together which constitutes the foundation of national citizenship.

Following on from this first argument is thus our second one, namely that the decomplexification and communitarisation within the academic sphere reflects the emergence of a citizenship in transition in Senegalese society. This transition takes the form of a dialectic tension or negotiation between what Le Blanc (2009) calls a "national citizenship" that corresponds to a legal status in a republic where the institutions remain secular, and a "cultural citizenship" inspired by Islam as a way of life for a predominantly Muslim population. "National citizenship" corresponds to the status of the Senegalese citizen who enjoys political rights (the right to vote, to stand for election, to benefit from equal access to employment, etc.) and acquired values that are traditionally associated with citizenship (public-spiritedness, tolerance and solidarity) that allows him or her to take part in public life. "Cultural citizenship" is characterised by the action of long-marginalized Senegalese religious actors who turn to Islamic cultural expression to assert their political rights and negotiate their participation in public and civic action (Mbow 2007: 49-50; Fall 1993).

In Senegal, the claim of cultural citizenship was initially put forward by Arabiceducated "counter-elites" (Coulon 1983: 70; Fall 1993; Kane 2003), but it is now increasingly appropriated by a new francophone Muslim elite trained in secular universities like UCAD. Like the "counter-elite", this new elite seeks to escape from its position of "second class citizenship" and claim their belonging to national citizenship. However, their claims, although critical vis-à-vis the state and its secular institutions, are not expressed outside the existing institutional framework and state control. To the contrary, in their expressions of their civic and political rights these Muslim citizens have a tendency to appropriate the rules of the democratic game to validate their project of an Islamic society and challenge the hegemony of the Westernised and secular elites who have led Senegal since its independence.

To account for the changes in the Senegalese public sphere in the current context marked by a resurgence of religiosity, we chose to focus on Cheikh Anta Diop University in Dakar as it represents a social laboratory. The choice of this university is based on three reasons. The first is historical. In fact, the University of Dakar is the oldest francophone university in West Africa. Its origins date back to 1918 with the creation of the Dakar School of Medicine by the French colonial administration. It became the University of Dakar on February 24, 1957 and was officially inaugurated on December 9 in 1959. It was the 18th public French university connected to the University of Bordeaux (see Chimoun 2008: 78). On March 30, 1987, the University of Dakar was named "Cheikh Anta Diop University of Dakar" (UCAD). It remained the only public university in Senegal until the creation, in January 1990, of Gaston Berger 
University (UGB) in St. Louis, and then the establishment of three other public universities since 2007.

The second reason motivating the choice of UCAD is the pivotal role it has played in the training of post-colonial African, and Senegalese elites in particular. From its creation until October 1970 the University of Dakar had a Pan-African vocation (Chimoun 2008). In addition to Senegalese students, it also hosted students from the former colonies of French West Africa and from French Equatorial Africa. The University was also the place where the clandestine Left organised its attempts to question the hegemony of the ruling class (Diop 1992: 434). And today it is the site where a francophone Muslim elite is emerging that seeks to challenge the dominance of westernised and secular elites (Ndiaye 2007).

The third and final reason is demographic. At its inauguration in 1959, UCAD included 1316 students. Since then, student numbers have grown in an exponential way. For example, between 2002 and 2011, the student population has grown from 28,585 to 56,773 , an increase of over $100 \%$ in almost ten years' time. Today, UCAD counts over 85,000 students coming from the thirteen regions of Senegal and from other African countries. Between 2001 and 2010, the number of students in this university was, on average, ten times higher than those of the UGB (the second largest public university in the country).

We used three data collection techniques to analyse the transformations in the university landscape. First, we used secondary sources, notably books, theses, dissertations, and press articles. These sources enabled us to capture the evolution of the student movement in its moments of greatness and decline, but also the emergence of Islam as an imposing factor in the academic sphere. Secondly, faced with a lack of data on religious associations at UCAD - particularly their number and the number of its members - we were fortunate to have access to qualitative and quantitative information resulting from research by Leonardo A. Villalón in 2007-09. ${ }^{2}$ This research included administering a questionnaire to 200 students of Muslim faith at UCAD. The questions covered topics as diverse as their degree of religiosity, their organisational affiliations, their conception of secularism, etc. The use of this data allowed for the identification of the most representative religious associations. Thirdly, we used our own experiences gathered during our tenure at the university ${ }^{3}$ which not only allowed us to familiarise ourselves with student structures, but also to identify and describe - through in situ observations - symbols of identity, the dress-code, and "territorialisation" of the campus by groups that claim ownership over certain spheres. This article is therefore the result of a triangulation of perspectives to account for changes in the university sphere at UCAD.

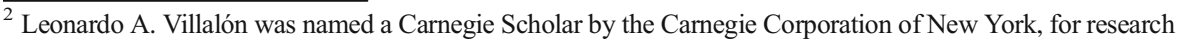
on a project entitled: "Negotiating Democracy in Muslim Contexts: Political Liberalization and Religious Mobilization in the West African Sahel." As part of that project he engaged a team of researchers to administer a questionnaire to 200 students at the Cheikh Anta Diop University of Dakar (UCAD) in 2008-09. Parallel surveys were carried out in Bamako (Mali) and Niamey (Niger). One of the authors of this article, Mamadou Bodian, was part of the team that conducted the Senegal survey. We are grateful to the Carnegie corporation for the funding and to Prof. Villalón for making the data available to us. Since there is no data available on students' religious organisation, we used this survey - and particularly students' responses on their organisational affiliation - to identify the most representative religious associations at UCAD.

${ }^{3}$ We each spent a good ten years at UCAD, during which we established close relationships with most of the Islamic as well as Christian associations such as Présence Chrétienne (Christian Presence).
} 
In the following sections, we will first discuss the events that have marked the emergence of the religious phenomenon on the university campus, by showing how the political and ideological choices of the student movement have been decisive. Subsequently, we will highlight local and international factors that have favoured the affirmation of religion and the communitarisation of the university sphere, before discussing empirical manifestations of the decomplexification of religion and communitarisation of the academic sphere. Finally, we will analyse to what extent the university functions as a space for localised expressions of social transformations and how the francophone Muslim elite trained in secular schools has appropriated the demand for cultural citizenship in order to demand a more inclusive national citizenship.

\section{Tracing the rise of revolutionary and secular ideologies and the affirmation of religion in university space}

Changes in the university landscape are not unrelated to the changing orientations of the student movement through the course of its history. These orientations are generally influenced by the political, economic and social context, and broadly fall into two categories: politico-ideological choices and corporatist approaches (see below). While the former choices have to some extent strengthened the protest activities of the student movement, the latter have precipitated its decline and contributed to the affirmation of Islam as the main source of cultural life within the university space.

\section{The ideological and political choices of the student movement}

The birth of the Francophone student movement in the 1930s initially took the form of a break with the colonial order. This approach was embodied, among others, by the student groupings around the Fédération des Étudiants d'Afrique Noire en France (Federation of Black African Students in France - FEANF) (Traoré 1984; Dieng 2003). In the French colonies of Sub-Saharan Africa, Dakar University was one of the places that challenged classical colonialism and - after independence - neo-colonialism embodied by local political elites. The Association générale des étudiants de Dakar (General Student Association of Dakar - AGED) was established in 1950 and became the Union générale des étudiants d'Afrique occidentale (General Student Union of West Africa - UGEAO) in 1957. It was one of the first institutions that formulated student demands in the early years of independence (Diop 1992: 442; Thioub 1992). UGEAO was characterised by 'the size of its recruitment base as well as by the consistency of its internationalist, anti-colonial and anti-imperialistic discourse' (Diop 1992: 442). Given that the student movement tended to display objectives that conflicted with the interests of the ruling class, the regime of Léopold Sédar Senghor (the first president of Senegal) constantly resorted to repression and ideological control in order to suppress any attempts to challenge the ruling system. In this context, the political and trade-union engagement of the UGEAO leadership led to the UGEAO's dissolution in November 1964. A year later, in February 1965, the Union Générale des Etudiants Sénégalais (General Union of Senegalese Students - UGES) was established, but it did not last for long before it was also dissolved (Diop 1992: 442; Bathily et al. 
1992). Student organisations supportive of the regime gained from these dissolutions, including the Fédération Nationale des Etudiants de l'UPS (National Student Federation which was a branch of the ruling party Union Progressiste Sénégalaise UPS), the Union Nationale des Etudiants Sénégalais (National Union of Senegalese Students - UNES), and the Fédérations des Etudiants Libres de Dakar (Federation of Free Students of Dakar - FELD).

From 1966 to 1974, the fate of the student movement was intrinsically linked to that of the leftist parties. During this period, political life in Senegal was marked by a relatively authoritarian regime that confined the political opposition to operating underground. In its attempt at challenging the neo-colonial state and its subjection to the interests of imperial powers, this political opposition - essentially consisting of the parties of the political Left - had organised itself around Marxism and the different variants of nationalism to oppose the ruling class. It also used trade unions of workers, teachers, and students as the main channels of expression. The role of the student movement in the anti-hegemonic project of the left is eloquently highlighted by Diop (1992: 435), when he writes, 'student activism has sided with the nationalist forces, which is why it has constantly enjoyed the support of the leftist intelligentsia.'

Already by 1966 , the students responded to the domination of the movement by structures affiliated to the regime by creating, respectively, the Union des Etudiants de Dakar (Union of Students of Dakar - UED) and the Union Démocratique des Etudiants Sénégalais (Democratic Union of Senegalese Students - UDES). These two unions became the catalysts of the first major struggles of the student movement in the post-colonial period before their dissolution in February 1971. These ideological and political struggles intensified in the late 1960s and centred around the resistance against the assimilationist educational model. They corresponded with the left-wing efforts to disrupt the establishment of Senghor's hegemony and the economic crisis that seriously put the living conditions of the urban middle class to the test (Diop 1992: 437). The crisis which erupted in May 1968 thus pitted Senghor's regime against trade union forces that blended political and corporate demands. ${ }^{4}$ According to Bianchini (1988), this crisis marked the achievement of a certain degree of cultural decolonisation. It also marked the beginning of a change in the orientation of the student movement towards more corporate demands.

\section{The corporatist approaches of the student movement}

Corporatist approaches are part of a process of de-politicisation (Bianchini 2004) and of "corporatist withdrawal" of the student movement. This change in direction was accelerated by the combination of three main factors. The first was the political liberalisation that had been going on since the late 1970s. In fact, Senegal's transition from a one-party system (from 1960 to 1974), to respectively a limited multi-party system (1974 to 1981) and subsequently a comprehensive multiparty system in the 1980 s contributed to the disintegration of the student movement. The second factor was the fragmentation of the student movement which actually only mirrored the ideological frictions within the

\footnotetext{
${ }^{4}$ May 1968 was one of the most significant events experienced by the Senegalese university system and the student movement. At UCAD, events began with corporatist protests in March of that same year. Students were fighting against the decrease of scholarships and their limitation to 10 months.
} 
Senegalese Left (Diop 1992: 439). Within the university space, these differences took the shape of a political battle for control of the student leadership. They seriously impeded the reorganisation of the movement in the late 1970s. For example, the Union Nationale Patriotique des Etudiants du Sénégal (National Patriotic Union of Students of Senegal UNAPES) was created in March 1979 under the influence of And-Jëf/Mouvement Révolutionnaire pour une Démocratie Nouvelle (And-Jëf political party/Revolutionary Movement for a New Democracy - AJ/MRDN) that was based on Maoism. Less than a week prior to the first constituent General Assembly of UNAPES, which was planned for 23 March 1980, another structure - the Union Nationale Démocratique des Etudiants du Sénégal (National Democratic Student Union of Senegal - UNDES) - was established by students and dissidents close to the Parti Africain pour l'Indépendance (African Party for Independence - PAI), a then clandestine left-wing communist Party. The third factor that accelerated the transition towards corporatist claims was the repressive attitude of the Senghor regime, the crisis of the university as an institution, and the subsequent reactions to financial survival that it provoked. On this matter, Diop (1992: 472) writes:

'The repression that had been increasing since 1968 favoured the emergence of a determined leadership which progressively abandoned the explicit antiimperialist line and the traditional revolutionary myths, and instead got involved in struggles that were much more rooted in the real world (improvements in living and study conditions).'

Since 1981, the student movement is only a shadow of its former self (Sy 2011), especially after the collapse of the Union Générale des Étudiant de Dakar (General Union of Students of Dakar - UGED) in 2004 against a backdrop of leadership quarrels. Multiple attempts to restore have not led to conclusive results. Therefore, the fragmentation of what should have been a strong central structure capable of solving student problems methodically and efficiently, inevitably resulted in sectoral protests led by corporatist associations of faculties or schools. General protests and demands were abandoned to the benefit of the specific demands of the various faculties. In short, the weakness of the protest "arm" of the student movement and its depoliticisation in favour of corporatist demands accelerated the decomplexification process of religious organisations that had already begun to emerge in the mid-1970s. These organisations increasingly imposed themselves as an alternative to the revolutionary and secular ideologies that had lost their ability to structure the university space. Several factors contributed to the affirmation of religion as an imposing actor in the university landscape.

\section{Factors that favoured the affirmation of religion in the university space}

Two main factors led to the decomplexification of religion at UCAD. The first was the international religious context symbolised by the Islamic revolution in Iran in 1979, which according to certain authors (Bianchini, 2004; Diop and Diouf 1990), contributed to the renewal of Islam in Senegal. However, we should not overemphasize the impact of the climate of religious agitation at the international level in the 
reconfiguration of the Senegalese religious field. Clearly, the Islamic revolution in Iran increased, but did not create, the sense of religious affiliation (Diop and Diouf 1990: 72). Two reasons support this argument. First, Islam in Senegal is not of Shiite orientation; it is essentially steeped in traditions of Sufi orders or tariqqa in the Sunni tradition ${ }^{5}$ Moreover, some Sufi orders (like the Mouride tariqa) had started their renewal process well before the Iranian revolution. Secondly, the types of players that were likely to be influenced by the Iranian Revolution were the reformist Islamic organisations which have fundamentally remained Sunni and were to greater or lesser extent inspired by Middle Eastern currents commonly referred to as "Wahhabi" or "Salafi". This reformist Islam had indeed been able to gain visibility and had penetrated certain strata of Senegalese society, but this was partly due to the actions and funding of Arab oil states and Sunni Muslim charitable organisations that had been investing in the construction of schools, Islamic centres and mosques. It is true nevertheless that the Iranian Revolution triggered, to some extent, 'an awareness of the revolutionary potential of Islam as a political and ideological system' (Bianchini, 2004: 201). This was manifested in the timid breakthrough of the religious movement at UCAD, symbolised by the struggle to build a mosque on the campus in 1986 . This breakthrough marked the beginning of an era in which other non-Sufi groups joined the list of Sufi-based associations within the university space.

The second factor that favoured the affirmation of religion at UCAD was the economic situation. From the early 1970s to the late 1990s, Senegal experienced an extremely difficult economic situation. The oil crises and severe drought in the early 1970 s, worsened by the peanut and phosphate crises in that same period, led to a significant decline in export earnings and large domestic and external imbalances (see Diouf 2002: 58-59). This economic crisis gave impulse to the "renewal" or restructuring of the very important Mouride order, largely as a response to the problems faced by the rural economy. The economic difficulties in fact caused the gradual decline of the agricultural sector. This situation forced some religious leaders, who had founded their influence on the cultivation of peanuts, to build a new legitimacy based on emigration. Copans (1980) describes this as the conversion from "peanut marabouts" to "emigration marabouts" (cited in Tall 2009: 147). ${ }^{6}$ It manifested itself in the expansion of the Mouride "Sufi mentality" beyond the original rural centres where it had first emerged (Diagne 1992: 290). Hence, while traditionally the main followers of this Sufi order were peasants, Mouridism did not take long to move beyond the rural sphere into the city. The rural population, in their effort to seek employment, spread the tarīqa into urban centres and maintained it through forms of social solidarity among the dahira $^{7}$ and also through forms of economic solidarity in the urban informal sector (Diop 1981; Diagne 1992: 290). This "re-territorialisation" of the Mouride tariqa continued into certain spheres, such as the academic, and fostered the integration of much of the intellectual elite within Mouridism (Diop and Diouf 1990: 80-81). This marked the beginning of a visible presence and expression of religion within the

\footnotetext{
${ }_{5}^{5}$ A Sufi order (or țariqa in Arabic) is a grouping of Muslims, often counting several thousands (or even millions) of members organized around devotion to particular religious figures or guides and distinguished by specific ritual practices. The largest orders in Senegal are the Tijani, the Mouride and the Qadiri tarīqas.

${ }^{6}$ Marabouts refers in Francophone Africa to religious leaders, usually of a Sufi order.

${ }^{7}$ A dahira is an association of followers of the same Sufi order. We thus talk of Mouride dahiras, Tijani dahiras, or Qadiri dahiras, etc.
} 
university campus, symbolized by the creation of the Dahira des Etudiants Mouride (Dahira of Mouride Students - DEM) in 1975.

The presence of religion at UCAD increased further due to the economic recession that reached alarming proportions during the 1980s. This situation was a result of the structural adjustment policies (SAPs) by the World Bank (WB) and the International Monetary Fund (IMF), and it was followed by the devaluation of the CFA Franc, which occurred in 1994 (see Banque mondiale 1992). The implementation of these SAPs resulted in a considerable reduction in public spending, the dismantling of local economic structures, and the exacerbation of difficulties in the social sectors, mainly in the educational sector that had entered into a phase of repetitive crises (Sy 2011: 282). At UCAD, the impoverishment of students and regular strikes by teachers, trainees, and the administrative staff further worsened the profound malaise that the institution was undergoing, especially in the early 2000s. At the social level, students protested against their precarious living conditions. Even if we note a certain increase in the numbers of scholarship recipients since the year 2000, the majority of students had to make do with an annual aid of 60,000 FCFA (approximately 92 Euros) per year. This economic hardship was accompanied by difficulties in relation to accommodation and medical care. In fact, each year thousands of new graduates arrived (and still arrive) at the university without a corresponding increase in housing and other facilities.

This situation explains why every year the students make the same social demands, including the improvement of the quality of their meals, attention for their medical care by the Centre des ouvres universitaires de Dakar (Dakar University Services Centre COUD), and reductions in rent and meal tickets (Sy 2011). In relation to the educational aspect, the matter of student overpopulation has become a burning issue. The massive increase in student numbers continues from year to year without a subsequent increase in the university budget. The creation of new universities between 2007 and 2008 has not been able to relieve the overcrowded University of Dakar. Thus, the university faces multiple challenges including a substantial brain drain, frustrations and profound disillusionments on the side of the students, and failure rates approaching $80 \%$ in some degree courses. ${ }^{8}$ This all has resulted in disturbances, especially caused by those who at the end of their studies only have a general education and find themselves as potential outcasts on the margins of the labour market, unable to secure employment upon graduation. It is therefore not surprising that students are falling back on forms of solidarity that allow them to overcome their precarious situation.

The multiplication of religious groups on campus should be seen as a response to a need for identity, but above all as a search for a social and psychological safety-net in the face of a precarious situation at the university. In this perspective, the religious movement cannot be analysed in isolation from the factors that have caused the mushrooming of identity-based associations (regional, ethnic, etc.) which populate the university campus (see Diop 2010: 47). The Islamic associations appear as the most visible category today, offering the students the possibilities to organise themselves as well as to develop forms of solidarity in order to mitigate their material, social and psychological discomforts. A situation like this gives a glimpse of the signs of a progressive "Islamisation" of the university space, a phenomenon which simultaneously is accompanied by a competition among religious organisations for the "conquest" of

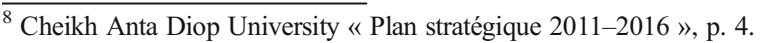


that space. This Islamisation began slowly in the late 1970s, picking up speed in the 1990 s with the democratic opening that enhanced the presence of religious actors in the public sphere in general and the deployment of their activities in the educational and academic spheres in particular. It takes the form of a decomplexification of religion, allowing students to reclaim their identity as Muslims and publicly express their Islamic cultural citizenship in a space that until recently has been dominated by revolutionary and secular ideologies. One interviewee argues that 'Now religion has a very important place at university; that is why many people now say they belong to the religion without complacency or without complex.'.?

\section{The decomplexification of religion and the logic behind the muslim students' capture of the university space}

There are two elements that have contributed to the growth and dynamism of the religious phenomenon within the university space. The first is the development of student organisations within Sufi orders. As we mentioned earlier, the establishment of the Dahira des étudiants mouride (Dahira of Mouride Students - DEM) at UCAD in December 1975 was a pivotal moment in this trend. Created under the caliphate of Sheikh Abdul Ahad Mbacke (Dramé 2011), this dahira went through several stages that have allowed it to become one of the most dynamic religious student organisations at UCAD. At the General Assembly of 1983, the DEM (whose board was predominantly composed of nonstudents) restated its orientations and refocused its efforts on the campus (Gomez-Perez 1998: 151). On 19 January1992, the dahira became the Hizbut Tarqiyyah which preached the "cult of excellence" and aimed to "ensure a cultural victory for Mouridisme" (Dramé 2011: 108). It should be noted that religious student activism was not only the prerogative of students who followed Mouridism. Tijani students also resorted to it and, in 1980, they set up the Dahira des étudiants tidianes (Dahira of Tijani Students - DET) with the approval of Serigne Abdoul Aziz Sy Junior, the current spokesman of the Tijani Sy branch. ${ }^{10}$ Drawing its legitimacy from its collaboration with the Caliph of that branch, the DET distinguished itself by its compliance with the instructions from the religious centre of Tivaouane and its adherence to the doctrinal line of the Tijani Sufi order (Gomez-Perez 1998: 151-152).

The second element that reflected the religious dynamism within university space was the construction of a mosque on the UCAD campus in 1986, which we referred to earlier. Managed exclusively by the Association des Étudiants Musulmans de l'Université de Dakar (Muslim Students Association of the University of Dakar AEMUD), this mosque has become a symbol of reformist (anti-Sufi) Islam at UCAD. In 1993, another reformist association was founded, sponsored by the Jama'atou Ibadou Rahmane (one of the most influential reformist organisations in Senegal). This is the Association des Élèves et Étudiants Musulman du Sénégal (Association of

\footnotetext{
${ }^{9}$ Interview with a member of the Committee of Imams from the Association des Étudiants Musulmans de l'Université de Dakar (Muslim Students Association of the University of Dakar - AEMUD), Dakar, September 2015.

${ }^{10}$ The Tijani Sufi order can be divided into three main subgroups, depending on the marabout and family disciples pledged allegiance to: the Tall, the Niasse, and the Sy families. The students of the DET belong to the latter founded by spiritual guide El Hadji Malick Sy.
} 
Muslim Pupils and Students of Senegal - AEEMS) which has become influential in Senegalese schools and universities (Ba 2008: 79-80). In the context of this flurry of activities by religious groupings in the 1990s, Senegalese Catholic students also mobilised themselves, creating several associations. These include, among others, the Association des Étudiants Catholiques du Campus (Association of Catholic Students of the Campus - AECC), the Groupement des Étudiantes Catholiques de la cité Aline Sitoé (Aline Sitoé Catholic Campus Student Group - GECCAS), the Jeunesse Estudiantine Catholique Universitaire (Catholic University Students' Youth - JECU), the Amicale des Normaliens Catholiques du Campus (Catholic Campus Normaliens Alumni Association - ANOC) and Présence Chrétienne (Christian Presence). But all these associations are affiliated with the Coordination des Etudiants Catholiques de Dakar (Dakar Catholic Student Coordination Body - CECD), the umbrella organisation whose headquarters is located in the Parish of St. Dominic in front of the university (Tamba 2005).

These developments swept the religious movement into a growth phase (Ndiaye 2007: 121). As one interviewee said: 'Today, all over the campus we see people praying. That did not exist before. There was only the Grand Mosque. But now, people are putting in place small mosques at the faculty level because they feel a need, a demand. At prayer times, students come out of their classrooms or reading rooms to pray. At the central library of the university, they [the authorities of the university] wanted to forbid people to pray there, but they could not because they have seen that the demand is high.' 11

These changes have contributed to the transformation of UCAD and the acceleration of the dynamics in the decomplexification of religion that today is expressed in two ways. First of all, it takes the form of a demarcation or rather territorialisation of certain campus spaces that are transformed into places of worship for different religious groups. Thus, the mosque has become the stronghold for students of the reformist mouvement (those of AEMUD) commonly known as "Ibaadou"12 while the ground floor of the pavilions ${ }^{13} \mathrm{~B}$ and $\mathrm{D}$, until recently, hosted the "Thiantacounes" or followers of Sheikh Béthio Thioune ${ }^{14}$ and the Tijani talibés, respectively. The halls in pavilions A and $\mathrm{N}$ were refurbished to accommodate the "Khassaide" 15 recitals by the Mouride followers and the songs of the Baaye Faal. The latter (the Baaye Faal) have turned the green space located in front of the Directorate of the Centre des ceuvres universitaires de Dakar (COUD) into their priory. It is even possible to detect the picture of their guide carved into the Boabab tree there. The part of the campus on which the female dormitories are located (the cité Aline Sitoé Diatta) houses a room called "the Qur'an room", which is managed by the AEEMS - a reformist organisation. Dozens of female

\footnotetext{
${ }^{11}$ Interview with the President of the University Section of the AEEMS, Dakar, September 2015.

12 This is a group of Muslims who advocate religious activism in daily life. They are critical of the traditional Sufi orders and aim to establish a new religious leadership in the community.

13 The pavilions are the student dormitories.

14 The word Sheikh is of Arabic origin. In the Islamic and Sufi religious tradition of Senegal, the Sheikh is a person who has fully realised his spirituality. He has accomplished the Way and can serve as a model and guide for those wishing to be like him and to his followers or talibés. This is the case with Béthio Thioune who was promoted to the rank of Sheikh by the late Saliou Mbacke (general Caliph of the Mourides) even though he has always maintained that he is not a scholar of Islam.

${ }^{15}$ This is a Mouride religious poem whose authorship is often attributed to the founder of the Sufi order, Sheikh Ahmadou Bamba.
} 
students are educated there in moral and religious life every year. For some years now the cité Aline Sitoé Diatta has lived according to the rhythm of religious songs of Sufibased associations, just like the part of campus that houses the men's dormitories. In addition to these places of worship, other areas of the campus, namely those housing the faculties, have been refurbished to serve as places for prayer. This is for example the case with the space in front of the University Library, the hall of the Faculty of Science and Technology, the space in front of the Faculty of Economics and Management and the (East) entrance of the Faculty of Law and Political Sciences.

The second way in which the decomplexification of religion is expressed is through the capture of student unions that were previously under the exclusive control of students adhering to revolutionary and secular ideologies. Such an evolution is the logical consequence of the lack of political and protest activity by the student movement at a crisis-stricken university whose functioning has become too complex to comprehend for the vast majority of students. Confronted with the precarious social and educational conditions and unable to identify the right channels and procedures (people, information systems, services, etc.) which could help them address these, students turn to community organisations to find social and psychological help (Diop 2010: 48). These community organisations in fact play the social role of integrating the students through the donation of restaurant tickets, setting up tutoring systems, and organizing cultural activities. As they contribute to the activities on the different parts of the campus, these community structures are gaining importance and visibility, at the same time as the student unions cease to play their roles as intermediaries between students on the one hand (whose interest they are meant to defend) and university and state authorities on the other. These formal representative bodies were the central pillars of political and ideological student life until the end of the 1970s and the only real corporatist units of the student community from the 1980s onwards. Yet, their own leaders - themselves facing the precariousness prevailing on campus and the toughness of the Senegalese labour market - had a tendency to use student unions as a springboard for obtaining "scholarships or political and administrative responsibilities" in the government (Zeilig 2004: 53-54).

It is therefore not surprising that given their strategies to capture social opportunities, religious and community organisations now seek to control the student unions. The fact that in the year 2000, the Association of Muslim Pupils and Students mobilized to take control of the presidency of the students association ("Amicale") ${ }^{16}$ of the Arts and Humanities Faculty (personified by Mamadou Dieng, known by the nickname "Dieng Ibaadou") is interesting for two reasons. First of all, it shows a concern to moralise student governing bodies by trying to manage public student affairs for the common good. Second, this opens the door to alliances for the control over the student governing bodies through which religious and community organisations position their members and mobilise themselves to elect them as student delegates. That is why the elections of the students unions are often a source of tension (within faculties) between the different political, religious and social forces aspiring to represent and defend the interests of students. These tensions reached their peak in 2008 when the violence following the election of the Delegates of the Student Association of the Faculty of Arts and Humanities (FLSH) caused dozens of students to be injured, and major material

\footnotetext{
16 The "Amicales" are the only legal structures to defend the interest of students.
} 
damage (Diop 2008). This conflict led to the organisation of a unique exam session that at the time was considered to be the lesser evil compared to the prospect of a wasted year at the FLSH. The removal of all faculty associations (Amicales) that was the result of this conflict further enhanced the power of attraction of religious and community organisations which were seeking to impose themselves as the only structure for the students' social and cultural development.

Seen from this perspective, it is thus possible to conclude that religious dynamism fed on the weakness and abandonment of revolutionary and secular ideologies at UCAD. Consequently, religion on campus has not acted as a parasite of the Senegalese student movement. Rather, it is the process of "depoliticisation" of that movement in favour of the corporatist option that has contributed to the affirmation and progression of the religious dimension. The latter imposes itself more and more as a focal point for cultural, worship and social activities in the university landscape. The conquest and territorialisation of university space by the religious associations has led to a discussion of the communitarisation of Islam in several - occasionally rivaldoctrinal discourses. It is thus necessary to show how religion was and still is expressed at UCAD.

\section{Communitarisation and expression of religious identities in the university space}

As should be clear by the discussion above, the Islamic religious landscape at the Cheikh Anta Diop University (UCAD) is far from homogeneous; rather, it presents itself as a complex cultural and doctrinal mosaic. There are no hard data available on the organisations on campus nor on the number of their members. But the survey data from Villalón's research suggests that there are several "religious microcosms", each of them with its own way of thinking and acting. To the extent that the religious sphere at UCAD reflects the structure of the Senegalese religious sphere in general, the religious associations on campus can be divided into two major categories: the groups linked to Sufi orders or tarīqas and the reformist or Sunni organisations. The group of Sufi disciples is structurally linked to the large Sufi orders in Senegal. This group includes associations affiliated with the Mouride tarīqa, such as Hizbut Tarqiyyah, the Dahira Madjmahoun Noreyni, the "Thiantacounes", and the Baaye Faal. In the group of Sufi disciples we also find the Dahira of Tijani Students (DET), Dahira of pupils and students followers of Baay Niass (DETBN), and the 'Amicale des Elèves et Etudiants Layènes' (AEL). The reformist group, on the other hand, consists of associations which are not affiliated to any Sufi order. Among these are the Association des Étudiants Musulmans de l'Université de Dakar (Muslim Students Association of the University of Dakar - AEMUD), the Association des Élèves et Étudiants Musulman du Sénégal (Association of Muslim Pupils and Students of Senegal - AEEMS), and the Pupil and Student Movement of Jama' atou Ibadou Rahmane (MEEJIR). These religious associations are making an effort to make Islam and Islamic culture more visible within the university space.

This religious landscape, manifestly plural and complex, naturally generates a growing sensitivity to the expression of different religious identities. It is possible to note two ways in which these identities are expressed. The first is through physical 
objects and clothing. In fact, wearing ostentatious signs has become a trend at UCAD. Some students affiliated with Sufi order, for example, proudly wear a medallion with a photograph of their spiritual guide. With regards to Sunnite students, signs and religious markers have become ubiquitous and visible such as the Islamic veil, long beards, etc. The second way in which religious identities are expressed is through active solidarity and a reproduction of religious and symbolic imagery. The most manifest ways of expression include worship rituals (daily and Friday prayers, Qur'an classes, Khassaïde recitals, the Guddi-adjuma, ${ }^{17}$ etc.) and the organisation of large-scale activities (such as a conference, "Thiant," 18 etc.). They allow us to understand how students rebuild in a material and symbolical way (through their religious practices and the rituals they perform) subjective belief constructions that nourish their collective identity and ensure the continuity of their religious organisations, thereby perpetuating the legitimating tradition of their cultural or doctrinal projects.

These modes of expression of identity present themselves as one of several individual and/or collective "responses" to deal with the changing realities at the university, which are embedded in the conflicts linked to the surrounding cultural tensions in Senegalese society. These tensions, which are not necessarily physical, express themselves through a "competition of culture and worship" in which both doctrinal groups (the Sufi groups and reformists) struggle to extend their spheres of influence within the university space. This rivalry is a result of the communitarisation of space and poses a problem of cohesion between the different tendencies in this space. It also contributes to the modification and the changing composition of the university sphere, which itself is a reflection of the transformations in the Senegalese public sphere in which there are growing demands for "cultural citizenship". This claim for a cultural citizenship actually constitutes a response to a historical hegemonic conception of Senegalese national citizenship, which tended to relegate religious Muslims and Senegalese Arabic-speakers to the category of second-class citizens.

\section{The university as a place of localised expression of social transformations}

The current trend towards the Islamisation of university space reflects that of the Senegalese public sphere in general. There is indeed a constant movement back and forth between the university - a space in which ideas and elites governing the nation are produced and/or reproduced - and society as a space in which these ideas and human resources are mobilised. This double movement creates an "osmotic effect", i.e. a mechanism of coming and going through which the social and university spaces influence and feed each other. Thus, the flurry of religious activity within UCAD should be regarded as both the reflection of endogenous social changes (at the university), but also and above all, as the localised expression of transformations that affect the religious sphere and Senegalese society in a general way. These transformations take the shape of a renegotiation of the initial

\footnotetext{
${ }^{17}$ These are the weekly prayer sessions that take place during the night from Thursday to Friday.

${ }^{18}$ Weekly ceremonies, religious songs in particular, which the talibés or those faithful to the Marabout Sheikh Béthio Thioune organise in honour of their spiritual guide.
} 
"Senegalese social contract" (Cruse O'Brien 1992: 83-93) which aims at finding a better way to account for Islamic culture within national citizenship.

\section{The renegotiation of the initial "social contract" and the emergence of cultural citizenship at ucad}

As we mentioned earlier, Islam in Senegal is characterised by the existence of important Sufi orders headed by a religious leader commonly known as Caliph, Since the colonial period, these Sufi leaders have contributed to the reproduction of the same secularized elites who, in turn, turned the secular state into a space which is favourable to the expansion of Sufi orders (see Villalón 1995). However, this politico-religious order that Cruse O'Brien (1992) describes as "the Senegalese social contract" based on clientelism gradually came undone due to the weakening of the state's financial capacity since the late 1970s, the fragmentation of the authority Sufi leaders (Gueye 2002), and the emergence of a trend that Samson (2005) calls 'Neo-Sufi'. The main players in this last trend - generally the numerous grandchildren or descendants of the founders of Sufi orders - each try to establish their spheres of influence (Villalón 1999). They claim a new legitimacy that is both religious and political, while remaining attached to their Sufi roots. Parallel to this trend, a reformist movement established itself separately from the Sufi organisations. Its origins date back to the colonial period but it went through a new dynamism in the 1970s (Gomez-Perez 2005). Located in the cities, the followers of the reformist movement generally advocate for a return to the Qur'an and the Sunnah. They seek to build their leadership in the Islamic religious space by making a continuous effort to undermine the maraboutic Sufi system. We can add another trend here, namely the general demands brought forward by the Arabiceducated elite. Long excluded from the political-administrative system, many of them campaign for "the removal of secularism from the constitution, the introduction of religious education in [public] schools, the stipulation of a new Personal Status Law based on the Shari'a, the establishment of Muslim courts, and the creation of a Ministry of Religious Affairs" (Mbow 2007: 49).

This is how the emergence of cultural citizenship as a result of a complexification manifests itself: through the actions of religious actors like the (neo)Sufi leaders, reformists, and Arabic speakers who are increasingly winning over the working class and the media in order to undertake a real effort of Islamisation by seeking the support of young people from working class neighbourhoods, schools and universities. This Islamisation process will create new spaces of socialisation maintained by preaching and Islamic propaganda (Bodian and Camara 2015). By competing for the recruitment of students in the secular public universities since the late 1970s, these religious organisations (both reformist and Sufi-based) are responsible for the emergence of a new profile of francophone students initiated into religion. While these francophone Muslim students claim to be advocating for a cultural citizenship, they tend to express it in an exclusive and tendentious way, thereby undermining the ideal of a peaceful pluralist coexistence.

In fact, Islam forms a constitutive dimension in the lives of most Senegalese. Religion transcends ethnic and regional specificities and structures the life of students in an open way, regardless of their social background, their education level, their ethnicity, or place of origin. But should we - at the current pace of Islamisation of the university space - 
realistically expect to see the development of a communitarianism which accepts religious pluralism, rather than the spectre of an exclusive, authoritarian and repulsive communitarianism which would question the principles of national citizenship within the university space? There are two reasons that explain why, until recently, the segmentation of identity as well as the multiplicity of culturally exclusive identities place a heavy burden on the rules that would guarantee a harmonious functioning of the university. First of all, the student does not consider him or herself to belong to the Muslim community on campus. He or she hides behind the doctrinal boundaries that separate him or her from fellow believers. Thus, the student's claim of affiliation with a specific doctrinal order (Tijani, Mouride, reformist, etc.) outweighs the sense of Muslim student identity or even the identity of being a Senegalese citizen. Secondly, the student makes a deliberate choice by which he or she does not feel bound by civic traditions (citizenship, justice, and tolerance) that should ideally be the most important principles of affiliation with the other students. Instead, the student only abides by the principles that govern the group to which he or she belongs. We can thus observe a limited conception of "cultural citizenship" that tends to "sectarianise Islam" on campus.

Therefore, cultural citizenship as it is experienced at the University of Dakar is an exclusive citizenship that has tended to challenge the peaceful coexistence of different religious communities. Clearly, ideological or doctrinal cosmopolitanism, when taken to certain extremes, could jeopardise the ideal of national citizenship based on social peace, justice and living together in this space of academic vocation. Although the relationships between these different religious groups are not always confrontational, certain events in which they clash indicate the presence of a constant tension. This is exemplified by the dispute in 1999 between Tijani students and the Muslim Students Association of the University of Dakar (AEMUD) concerning the management of the UCAD Mosque. Apart from such differences in opinions, there are others that undermine the dialogue between individuals belonging to different associations. ${ }^{19}$ In the absence of mechanisms to govern pluralism in the university space, the situation may be further exacerbated in the current context where religious plurality intersects with ethnic and geographical identities. ${ }^{20}$ Whether this trend will continue is unclear.

Since 2011, a number of initiatives have been undertaken that appear to be defusing tension and leading to an improved climate for dialogue between different religious organisations on campus. For instance, reformists are taking a more subtle tack in recent years, avoiding confrontation with Sufis and attempting to build on a common ground of Islam. This is particularly the case of activities jointly organized by the AEEMS and Christian Presence association. In 2011, the three main reformist organisations at UCAD set up an Action Committee that serves as framework for dialogue and cooperation between them. While Sufis and reformists may still criticize one another, they often seem to negotiate and compromise ("maslaha") in public. Obviously, there is a strong sense of competition between various Sufi groups, but there are also many performances of respect between them. For example, each dahira

\footnotetext{
${ }^{19}$ In 2004, for example, a quarrel between two roommates - one a Sunnite and the other a Mouride talibé or disciple - provoked broader fighting between groups from the two communities. A photograph of the general Caliph of the Mourides hanging on the wall of the room and torn by the Sunnite roommate was said to have caused the quarrel.

${ }^{20}$ It is thus also possible to observe the emergence of asssociations of certain ethnic minorities and of those hailing from specific regions, cities and villages.
} 
sends representatives to attend competing big events of other dahiras. Other activities, such as "the day of the student", are organized and bring together all Islamic associations evolving at UCAD. More importantly, in March 2014, the Director of the Centre des auvres universitaires de Dakar (COUD) took the decision to restore order on campus, regulating religious activities. This measure still remains in force, even though it has not found initial support among students, especially from those who went on to create the Collectif des dahiras d'étudiants (Collective of Students' Dahiras - CODE), and accused him of violating religious freedoms. ${ }^{21}$

In sum, tracing the development of religious activism at UCAD has allowed us, on the one hand, to question the traditional perception of the university as a neutral space protected from the influences stemming from its social environment. Indeed, the principle of academic freedom and openness (Diouf and Mamdani 1994), which is supposed to protect the academic community from any outside interference and help to build a democratic and tolerant space is increasingly being threatened. On the other hand, the religious activism at the University of Dakar reveals a process of renegotiating modernity and citizenship in Senegal. Students who have been initiated into religion in secular francophone universities greatly contributed to this redefinition of citizenship (Ndiaye 2007). These students tend to appropriate the claim of cultural and Islamic citizenship which had been increasingly under pressure from the Arabiceducated elite and Islamic organisations, and use it to formulate the demand for a more inclusive national citizenship.

\section{Towards an inclusive national citizenship: the role of the francophone muslim elite}

The structure of democratic relations within Senegalese society is traditionally discussed from a dichotomous perspective which pits the Western-educated elite against the Arabic-educated "counter-elite" (Fall 1993; Mbow 2007). The first one can be described as a "secular francophone elite" and is the product of the Senegalese school system which is inspired by France in terms of its orientation, content, and language of instruction. During the colonial period, this school system was the vehicle for the policy of assimilation that favoured the emergence of the first socio-political elites who governed Senegal after it obtained international sovereignty. This sociopolitical elite, which generally bought into the Western ideas of modernity, has always preserved the public and secular image of the state and of its institutions that still bear the imprint of the hegemony of the French language, the language of public administration. In such a structural context, Senegalese citizens educated in Islamic institutions or in Arabic language found themselves being disqualified from all meaningful participation in public and administrative life. Having completed their Arab-Islamic education, many of them had to open their own Qur'anic schools (daara) or use their symbolic capital to assert their supremacy and legitimacy in the religious sphere and in the sphere of preaching (Bodian and Camara 2011). Increasingly, they are trying to get out of their situation as "second class citizens". The fact that they claim the Arabic

\footnotetext{
${ }^{21}$ See 'Ucad- Hébergement, activité religieuse: Le Coud engage des mesures': http://news.adakar.com/h/ 7654.html, March 4, 2014; 'Intrusion de la religion à l'université' Les dahiras prêts à affronter le recteur: http:// www.enqueteplus.com/content/intrusion-de-la-religion-\%C3\%A0-luniversit\%C3\%A9-les-dahiras-pr\%C3\% AAts-\%C3\%A0-affronter-le-recteur, March 4, 2014
} 
language as a working language and express themselves in it or in other national languages in the media in order to discuss national affairs (see Mbow 2007: 49), reveals the elitist assertion of this Arabic-educated elite who tend to challenge the institutional heritage and hegemony of the French language. Fall (1993: 200) aptly describes this claim of cultural citizenship when he writes:

\section{'The demands of Islam, when linked to Arabisation, are strong and multifaceted: they refer both to the education sector (which it would like to conform to the canons of Islamic morality), the promotion of the Arabic language (which it considers a sacred language because it is the language of the Koran but the Arabic speakers would like to see it promoted as the national language), as well as at the critique of secularism.'}

In the current context of the re-Islamisation of Senegalese society, the critique on national citizenship (which became fragmented) is being appropriated by the Muslim elite educated in francophone universities such as UCAD. This "francophone Muslim elite" and the "Arabic-speaking Muslim elite" share the societal project of raising the status of the Arabic language and of promoting Islam as a political, economic and social alternative. This shared project bypasses the rivalry between cultural citizenship and national citizenship and also tends to purge the concept of cultural citizenship of its tendentious aspects. This synthesizing effort is embodied by the intellectuals who are members of the Centre d'étude et de recherche islam et développement (Centre for the study and research on Islam and development - CERID). This association brings together a part of the intelligentsia who is educated in the Western school system and aims to reconcile Western notions of progress with Islamic values. Also, the association strives "to work towards the cleansing of Senegalese Islam by getting rid of its "elitist" character and its tendencies towards "sterile regionalism" and by promoting its unity, not around “certain families”, but based on the Qur'an and Sunnah' (Fall 1993: 200).

The "francophone Muslim elite" mentioned above is not only experiencing an upward social mobility based on the education system, but is also keen to participate politically using the mechanisms of the democratic game. The entrance of the francophone Muslim elite into the political game will mark the beginning of a new era of competition with the secular political elite over the management of public affairs. It will ride on two registers of legitimacy. The first is a moral register, which is attributed to them based on their status as believers. The second is a political register, derived from the rules of political pluralism. They also appeal to Islamic ethics whose principles they claim to embody, and accuse the Westernised and secular elite of being responsible for the socio-economic malaise and the underdevelopment of the country.

\section{Conclusion}

In this article, we have tried to show how the assertion of Islamic religion within the university space attests to the progressive decline in the ability of revolutionary and secular ideologies to structure this space. This ideological decline has brought with it the decomplexification of the religious sphere and the communitarisation of the university space. These two dynamics reflect the changes in the religious landscape 
in Senegal, itself characterised by strong demands for a cultural citizenship that can hold its own vis-à-vis a conception of national citizenship that is of francophone and secular orientation, and which does not give much room for Arabic speakers in public policy and administration.

In the context of the Cheikh Anta Diop University, the demand for cultural citizenship intersects with a process of decomplexification of religion, and this produces two interesting dynamics. Firstly, the Muslim students, appropriating the idea of a religious citizenship (citizenship based on worship), have tended to increase the communitarisation of space to the extent that Islam has been "sectarianised" into several, occasionally rival, organisations. Secondly, the decomplexification of religion has produced a type of francophone believer who tries to reconcile national citizenship with cultural and/or religious citizenship by appropriating his or her political rights and the rules of the democratic game. The main mode of action of these believers, even if it is sometimes rooted in challenging the political system (especially through the contestation of state secularism and its institutions) is generally one of participation. In other words, the "francophone Islamic elite" aspire to control the system but not to reject it. These dynamics reflect a profound transformation of Senegalese society. Given that the involvement of religious actors in the public sphere and in politics is becoming increasingly apparent, the demand for a more inclusive and pluralist citizenship is likely to be an important issue on the agenda of Islamic activists in Senegal.

Open Access This article is distributed under the terms of the Creative Commons Attribution 4.0 International License (http://creativecommons.org/licenses/by/4.0/), which permits unrestricted use, distribution, and reproduction in any medium, provided you give appropriate credit to the original author(s) and the source, provide a link to the Creative Commons license, and indicate if changes were made.

\section{References}

Ba S. (2008). L'implication des femmes dans les projets de société islamique: le cas des militantes de l'Association des élèves et étudiants musulmans du Sénégal (A.E.E.M.S), Mémoire de maitrise, Département de sociologie, Université Cheikh Anta Diop de Dakar.

Bathily, A., Diouf, M., Mbodj, M. (1992). Le mouvement étudiant sénégalais, des origines à 1989. In H. d'Almeida-Topor, Georg, O., Coquery-Vidrovitch, C., Guitart F. (Ed.), Les jeunes en Afrique: la politique et la ville (pp. 283--310). 2nd volume. Paris: L'Harmattan.

Bianchini, P. (1988). Crises et réformes du système d'enseignement sénégalais (1968-1986): contribution à Une sociologie politique de l'éducation en Afrique noire. Thèse de 3e cycle. Bordeaux: IEP.

Bianchini, P. (2004). Ecole et politique en Afrique noire: sociologie des crises et des réformes du système d'enseignement au Sénégal et au Burkina Faso (1960-2000). Paris: Karthala.

Bodian, M., \& Camara, E. M. S. (2011). Le Rôle des religieux dans l'espace public et dans l'amélioration du débat public Sur la bonne gouvernance. In M. Kaag (Ed.), Islam et engagement au Sénégal (pp. 81-107). Leiden: African Studies Centre, Leiden University.

Bodian, M., \& Camara, E. M. S. (2015). Islam et espace public au Sénégal: les acteurs religieux dans l'amélioration du débat public Sur la bonne gouvernance, In Kaag M. et al. (Eds.) Islam et engagement au Sénégal (pp. 113-141). Paris: Karthala.

Chimoun, M. (2008). La recherche scientifique dans les universités africaines: le cas de l'université Sénégalaise. In S. Bett (Ed.), La recherche scientifique et le développement en Afrique - Idées nomades (pp. 77-86). Paris: Karthala.

Copans, J. (1980). Les marabouts de l'arachide. Paris: Le Sycomore.

Coulon, C. (1983). Les musulmans et le pouvoir en Afrique noire. Paris: Karthala. 
Cruse O’Brien, D. (1992). Le contrat social sénégalais à l'épreuve. Politique Africaine, 45, 9--20 (republished in an updated version as: Les négociations du contrat social sénégalais. In D. Cruse O’Brien, Diop M. C., Diouf M., (Ed.) (20 02). La construction de l’État au Sénégal (pp. 83-93). Paris: Karthala.

Diagne, S. B. (1992). L'avenir de la tradition. In M.-C. Diop (Ed.), Sénégal: trajectoires d'un État (pp. 279298). Dakar: CODESRIA.

Dieng, A. A. (2003). Les premiers pas de la Fédération des étudiants d'Afrique noire en France, FEANF, 1950-1955 : de l'Union française à Bandung, Paris, Budapest, Torino.

Diop, M. C. (1981). Fonctions et activités des dahira mourides urbains (Sénégal). Cahiers d'études africaines, 21(81-83), 79-91.

Diop, M. C. (1992). Le syndicalisme étudiant: pluralisme et revendications. In M. C. Diop (Ed.), Sénégal: trajectoires d'un Etat (pp. 441-477). Paris: Karthala.

Diop, M. A. (2008). Violences à l'UCAD: 30 blessés dont 1 grièvement. Resource document: http:// amadou53.seneweb.com/news/Societe/violences-a-1-ucad-30-bless-s-dont-1-grivement_n_17292.html. Accessed 11 June 2013.

Diop, B. (2010). Le feu sacré de la liberté: Mon combat pour la jeunesse africaine. Paris: L'Harmattan.

Diop, M. C., \& Diouf, M. (1990). Le Sénégal sous Abdou Diouf: État et société. Paris: Karthala.

Diouf, M. (2002). Culture politique et administrative et réforme économiques. In D. C. Cruse O’Brien, M.-C. Diop, \& M. Diouf (Eds.), La construction de l’Etat au Sénégal (pp. 49-61). Paris: Karthala.

Diouf M. \& Mamdani, M. (1994). La liberté académique en Afrique. Dakar: CODESRIA and Paris: Karthala.

Dramé, S. (2011). Le musulman sénégalais face à l'appartenance confrérique. Paris: L'Harmattan.

Fall, M. (1993). Les arabisants au Sénégal. Contre-élite ou courtiers? In R. Otayek (Ed.), Le radicalisme islamique au Sud du Sahara (pp. 197-212). Paris: Talence.

Gomez-Perez, M. (1998). Associations islamiques à Dakar. In O. Kane \& J.-L. Triaud (Eds.), Islam et Islamismes Au Sud du Sahara. Paris: Karthala.

Gomez-Perez, M. (2005). Généalogie de l'Islam réformiste au Sénégal des années 1950 à nos jours: figures, savoirs et réseaux. In F. Laurent, André, M. et al. (Ed.). Entreprises religieuses transnationales en Afrique de l'Ouest (pp. 193-222). Paris: Karthala.

Gueye, C. (2002). Touba: La capitale des mourides. Paris: Karthala, p. 281.

Kane, O. (2003). Intellectuels non europhones. Document de travail. Dakar: CODESRIA.

Le Blanc, M. N. (2009). Foi, prosélytisme et citoyenneté culturelle: le rôle socio-politique des jeunes arabisants en Côte d'Ivoire au tournant du 21e siècle. In G. Holder (Ed.), L'islam, nouvel espace public en Afrique (pp. 173-196). Paris: Karthala.

Mbow, P. (2007). Que signifie être intellectuel en Afrique? In A. Kouvouama et al. (Eds.), Figures croisées d'intellectuels: trajectoires, modes d'action, productions (pp. 41-56) .Paris-Karthala

Mondiale, B. (1992). Revitalisation de l'enseignement supérieur au Sénégal: les enjeux de la réforme. Banque Mondiale: Washington D.C.

Ndiaye, A. I. (2007). Le fait religieux dans l'espace universitaire. In L'Afrique des associations: entre culture et développement (pp. 117-128). Dakar: CRESPO-Karthala.

Samson, F. (2005). Les marabouts de l'Islam politique le Dahiratoul Moustarchidina Wal Moustarchidaty, un mouvement néo-confrérique sénégalais. Paris: Karthala.

Sy, H. (2011). Grèves scolaires et universitaires au Sénégal: critique de la raison militante. Liens 14 Fastef-UCAD.

Tamba, M. (2005). La pratique religieuse dans un espace institutionnellement laïque: L'exemple de l'Université de Dakar. Colloque international d'éducation comparée, Éducation, religion, laïcité, quels enjeux pour les politiques éducatives? Quels enjeux pour l'éducation comparée?, 19-21 October 2005.

Thioub, I. (1992). Le mouvement étudiant de Dakar et la vie politique sénégalaise: la marche vers la crise de mai-juin 1968. In H. d'Almeida-Topor et al., (Ed.), Les jeunes en Afrique: La politique et la ville (pp. 267-281). 2nd volume. Paris: L'Harmattan.

Traoré, S. (1984). La Fédération des Etudiants d'Afrique noire (FEANF). Paris: L'Harmattan.

Villalón, L. A. (1995). Islamic society and state power in Senegal: disciples and citizens in Fatick. Cambridge: Cambridge University Press.

Villalón, L. A. (1999). Generational Changes, Political Stagnation, and the Evolving Dynamics of Religion and Politics in Senegal. In Africa Today 46:3/4. 1999, pp. 129-147.

Zeilig, L. (2004). En quête de changement politique: la mobilisation étudiante au Sénégal, 2000-2004. Politique africaine, 96 (décembre), 39-58). 